\title{
Spatial and Temporal Patterns in Post-Fire NitRogen DYNAMICS OF LODGEPOLE PINE FORESTS IN THE GREATER YeLLOWSTONE ECOSYSTEM
}

\author{
MONICA G. TURNER \ DEPARTMENT OF ZOOLOGY \\ UNIVERSITY OF WISCONSIN $\downarrow$ MADISON \\ WILLIAM H. ROMME $\downarrow$ DEPARTMENT OF FOREST, RANGELAND, AND WATERSHED \\ STEWARDSHIP $\uparrow$ COLORADO STATE UNIVERSITY $\uparrow$ FORT COLLINS \\ DANIEL B. TINKER $\downarrow$ DEPARTMENT OF BOTANY \\ UNIVERSITY OF WYOMING LARAMIE
}

\begin{abstract}
$\uparrow \quad$ INTRODUCTION
Our study addresses the effects of firegenerated landscape patterns, or variability in structure and composition of successional forest communities, on ecosystem processes such as biogeochemical cycling and productivity. Forest fire is a well-studied disturbance, yet little is known about the long-term implications of a fire-generated landscape mosaic for ecosystem processes. In particular, the dynamics of nitrogen turnover, availability, and sequestration following standreplacing fire in conifer forests, has received surprisingly little research attention, even though nitrogen is thought to be a limiting factor in most coniferous forests (Smithwick et al. in press). Our current work in Grand Teton and Yellowstone National Parks builds on our previous and continuing long-term studies of the causes and consequences of fire in the Greater Yellowstone Ecosystem (Turner et al. 2003). The fires of 2000 provided new opportunities for studying spatial and temporal variation in ecosystem processes soon after severe disturbances and how these patterns develop and change through time.
\end{abstract}

In 2001 we initiated new studies in areas of Grand Teton National Park that burned in 2000. These studies were designed to fit within a broader context of research that in subsequent years will also include burned areas in Yellowstone National Park. We are asking the following questions:

(i) Does the spatial heterogeneity and pattern of processes such as aboveground net primary production (ANPP), nitrogen mineralization, and decomposition change with time since fire?

(ii) How quickly do spatial patterns in processes develop following a large fire?

We hypothesize that ecosystem processes are relatively homogenous immediately following fire, but become more heterogeneous as the stands develop during the first few years of succession. By comparing spatial and temporal heterogeneity in ecosystem processes in similar sites that burned in 1988, 1996, and 2000, as well as in the same sites over time, we can determine whether the postfire patterns of tree saplings increase the spatial heterogeneity in process rates. 


\section{$\downarrow$ METHODS}

We initiated field studies during the summer of 2001 in ten 0.25 -ha plots located within two large, severe fires that occurred during the summer of 2000: the Moran fire, on the west side of Jackson Lake near the base of Mount Moran; and the Glade Fire, in the Rockefeller Parkway lands just south of the boundary of Yellowstone National Park. Within each of these two large burned areas, five study plots were established in areas of stand-replacing fire, for a total of ten plots. In each of the two burned areas, three of the plots were located in crown fire and two were in severe-surface burns. Over the next $3+$ years, we will monitor the development of postfire vegetation, sampling the number and species of tree seedlings and the percent cover (by species) of all other vegetation. We will also measure the availability of inorganic nitrogen using ion-exchange resin that is incubated in the field for a year in small soil cores (Binkley et al. 1992); the concentration of nitrogen in the vegetation of different species in the burned plots and adjacent unburned locations; and the presence and abundance of soil microbial functional groups. We are using a scaled sampling design to detect the spatial scale of variation in nutrient availability, and we are re-measuring these sites through successional time. We will estimate herbaceous ANPP and leaf area (Turner et al. in press) in these recently burned stands because we expect the rate of recovery of these processes to influence nitrogen and carbon availability. Changes in spatial patterns and in mean rates are being tracked through time by repeating the measurements in 2002, 2003 and 2004.

\section{RESULTS}

No results are available yet, since our focus in 2001 was to establish the study plots. We will have preliminary results to report next year, with final results and interpretations in 2005.

\section{SIGNIFICANCE}

Our study will contribute to the ability to predict broad-scale patterns of ecosystem processes, understanding the variability within and among ecosystems, and the consequences of disturbance for ecosystem function. Our study also will contribute to understanding potential effects of fire in natural areas of the northern Rocky Mountains. Finally, our research will provide the first integrated study of spatial variability in post-fire succession and the consequences of this variability for a variety of ecosystem processes across a large heterogeneous landscape.

\section{$\downarrow$ Literature Cited}

Binkley, D., R. Bell. and P. Sollins. 1992. Comparison of methods for estimating soil nitrogen transformations in adjacent conifer and alder-conifer forests. Canadian Journal of Forest Research 22:858-863.

Smithwick, E. A. H., M. G. Turner, M. C. Mack, and F. S. Chapin III. In press. Post-fire soil N cycling in northern conifer forests affected by severe, stand-replacing wildfires. Ecosystems.

Turner, M. G., W. H. Romme, and D. B. Tinker. 2003. Surprises and lessons from the 1988 Yellowstone fires. Frontiers in Ecology and the Environment1:351-358.

Turner, M. G., D. B. Tinker, W. H. Romme, and D. M. Kashian. In press. Landscape patterns of sapling density, leaf area, and aboveground net primary production in postfire lodgepole pine forests, Yellowstone National Park (USA). Ecosystems. 